\title{
ХРОНИКА CHRONICLE
}

DOI: 10.22363/2312-9182-2018-22-1-195-199

\section{REVIEW of Laura Alba-Juez and J. Lachlan Mackenzie. 2016. Pragmatics: Cognition, Context \& Culture. Madrid: McGraw Hill, 307p.}

\author{
РЕЦЕНЗИЯ НА КНИГУ Laura Alba-Juez \\ and J. Lachlan Mackenzie. 2016. \\ Pragmatics: Cognition, Context \& Culture. \\ Madrid: McGraw Hill, 307p.
}

Among the many courses in Linguistics that I have taught over the past 40 years, an introduction to pragmatics has been a regular fixture. In fact, the first pragmatics textbook I read and used was published exactly 40 years ago, written in Dutch by Teun van Dijk (see van Dijk 1978). Since then, dozens of textbooks have appeared, from Levinson's (1983) and Leech's (1983), via Grundy's (1995) and Verschueren's (1999), to Huang's (2014) and Senft's (2014), to mention only a few of the ones written in English. The newest title in this genre is already different from its predecessors in that it has two authors instead of one, Laura Alba-Juez and J. Lachlan Mackenzie, a Professor of English Linguistics and a retired Professor of Functional Linguistics, from Madrid and Amsterdam respectively. Before asking what else distinguishes this textbook from older ones, I will give a short summary of its structure and content.

The first of the six chapters (pp. 1-33) provides a general overview of the field of pragmatics. The distinction is introduced between micro- and macropragmatics (better seen as poles on a continuum), and the three C's in the subtitle of the book, Cognition, Context and Culture are motivated. In pragmatics, context has always been a central notion, since the discipline is about how to do things with words in different contexts. Culture and cognition are, however, standardly given less attention in pragmatics textbooks, so the explicit mention of these two dimensions raises certain expectations regarding the profile of the book.

The second chapter (pp. 35-72) deals with speech acts. Austin's insight (1962) that using language always implies doing something (asking, informing, requesting, etc.) can be seen as the historical starting point of pragmatics. Chapter 3 (pp. 73-127) discusses a second classic ingredient of pragmatic theorizing: Grice's implicatures. Presupposition, inference, and (deictic) reference are also treated here. (Im)politeness theories are the focus of Chapter 4 (pp. 129-180), followed by Chapter 5 on Relevance Theory (pp. 181-214). 
After these five chapters, each dealing with one of the fundamentals of pragmatic theorizing, the concluding Chapter 6 (pp. 215-258) explores "Other topics of interest in pragmatics": Pragmatically relevant linguistic features of prosody, syntax and the lexicon, evaluative and expressive language use, historical pragmatics, and the use of language in the new media on the internet ('Cyberpragmatics', as the authors call it, following Yus 2011). The book concludes with a list of references (pp. 259-281), keys to the self-evaluation questions and exercises (pp. 283-299), and a subject index (pp. 300-307).

Pragmatics is a vast interdisciplinary field, which makes it practically impossible to cover the complete field in an introductory textbook. Depending on the personal expertise of the authors, their view of the field, and the topics that are 'in' at the time of writing, certain subfields will be focused on and others will remain somewhat in the background. For example, Gunter Senft's textbook Understanding Pragmatics (2014) has no special chapters on Politeness or Relevance Theory; instead, it contains a chapter on Conversation Analysis, as Levinson's (1983) introduction had already done. How about the choices made in the book under review? There is no separate chapter on Conversation Analysis or Narration Analysis. In the view of the authors, pragmatics "provides important tools and basic concepts" and is a crucial source for Discourse Analysis, but it is not the same thing. They have therefore not included those "broader, more empirically-oriented discipline[s]", believing them to be better included within the general field of Discourse Analysis (p. 15).

The decision to focus on the immediate context of language use and leave the wider context (the complete text or conversation) in the background can be related to the distinction made between micro- and macropragmatics (pp. 14-15). Micropragmatics tends to pay more attention to aspects like presuppositions, intentions, implicatures, directly related to the here and now of the speech act, whereas macropragmatics pays more attention to the wider context like the overall structure of a text or the genre-specific properties of a text or conversation. For an introductory course, this decision might be justified, although some authors (cf. Enfield and Sidnell 2017) are critical of such a restriction.

The previous comment had to do with Context, the second of the three C's in the subtitle of the book. What about the other two, Culture and Cognition? Let us start with culture. The last section of the first chapter is devoted to 'Pragmatics and culture' (pp. 23-27). The authors discuss the problems involved in defining what a culture is. They warn against speaking in too generalizing a way about 'Spanish culture' vs. 'AngloSaxon culture', or whichever other culture. This justified scepticism towards making simplified statements about cultural differences may have played a role in their decision to pay only restricted attention to cultural aspects in the rest of the book. The relevance of cultural variation for the study of language use is acknowledged but, for example, culturespecific communicative styles (cf. Larina 2015) are not discussed in detail. In a similar vein, the subfield of Intercultural Pragmatics (cf. for this the textbook by István Kecskés, 2014, reviewed in issue 19:4, 2015, of this journal) is mentioned but not elaborated upon. However, in the last chapter Alba-Juez \& Mackenzie devote a section (6.8) to language 
use in the new media, a context of increasing cultural importance. The fact that in 2018 the publisher John Benjamins is starting up a new journal called Internet Pragmatics, testifies to the relevance of this field of study.

The first $\mathrm{C}$ in the subtitle is Cognition. The cognitive process of interpretation in context is an important aspect of pragmatic theorizing. Presupposition, inference, implicature, joint attention etc., all relevant aspects of such cognitive processes, receive due attention. But what profiles this book in a special way is the fact that it has incorporated the 'emotional turn' in cognitive sciences (cf. Damasio 1994). In everyday life, cognition is not neutral to 'the world'; it is constantly evaluating referents, interactional participants, and action alternatives. This emotional turn should have consequences for the cognitive dimension of pragmatic research, as the authors rightly argue in sections 6.3 and 6.4. They draw their inspiration for elaborating on this dimension from Appraisal Theory, as developed against the background of Halliday's Functional Grammar (cf. Martin \& White 2005, and Thompson \& Alba-Juez eds. 2014, reviewed in this journal, issue 19: 4, 2015). Important subsystems in Appraisal theory are Attitude, Engagement and Graduation. Attitude has to do with evaluating objects and other people's behavior, Graduation with the intensity of the evaluation and Engagement with viewpoint and stance, involving the question whether knowledge and evaluation are attributed to one's own perspective, to that of another person or to 'everybody' (for a recent study on engagement from a primarily grammatical perspective, see Evans et al. 2017). An important component of appraisal is emotion, and more generally, it can be said that emotion drives and determines language use to a considerable extent (for a grammaticalsemantic perspective on emotion, see Foolen 2016). Alba-Juez \& Mackenzie's plea for more attention to be paid to evaluation and emotion in future pragmatic research can only be wholeheartedly supported (see also the research papers in the present special issue of this journal).

A feature of the book that will strike every reader who is familiar with other pragmatic textbooks is its clear structure. Each chapter starts by succinctly stating its main objective and topics and ends with a summary in the form of a numbered list of items and insights that the student should have learned from the chapter. Via (multiple choice) self-evaluation questions and exercises at the end of each chapter, students can test their knowledge and apply this to new pragmatic problems. The chapters are full of examples, tables, figures and pictures, which all contribute to the didactic quality of this textbook. The fact that the first author is a professor at the Spanish National University of Distance Education (UNED) will certainly have played a role here. Distance learning students have to study independently of the weekly motivation of classroom meetings, and so the teacher's role as a provider of structure and motivation has to be partly taken over by the textbook. But these didactic properties of the book will certainly do no harm if used in a regular (presential) course.

Another positive feature is a good balance of references to classic work in pragmatics and to more recent publications and developments. About half of the more than 300 references are dated from 2000 onwards. Besides following up on these references, teachers and students can turn to (chapters of) other recent textbooks. As this review 
may have made clear, Cognition is more strongly developed in the present book than Culture. Courses that want to expand on the latter aspect could turn to (chapters of) Senft (2014), who focuses more on social-cultural-anthropological approaches to pragmatics. On a more advanced level, there are the Handbooks of Pragmatics, with contributions by specialists on specific subfields (cf. Bublitz et al. eds., starting in 2011, Huang ed. 2017, and Barron et al. eds. 2017, to mention only the most recent ones).

Over the past 40 years, the 174 pages of van Dijk's (1978) introduction have grown into a whole shelf of textbooks and handbooks. For students with only a general background knowledge of Linguistics, the choice of Alba-Juez \& Mackenzie's book is certainly a good one. The chance that they will want more or even choose to write a thesis from a pragmatic perspective will be higher than average if they start with this stimulating textbook.

(C) Ad Foolen, 2018

\section{REFERENCES}

Austin, John L. (1962). How to do things with words. Oxford: Clarendon Press.

Barron, Anne, Gu, Yuego, and Steen, Gerard (Eds.) (2017). The Routledge handbook of pragmatics. London and New York: Routledge.

Bublitz, Wolfram, Jucker, Andreas H., and Schneider, Klaus P. (Eds.) (2011). Handbook of pragmatics [13 volumes]. Berlin: de Gruyter Mouton.

Damasio, Antonio (1994). Descartes' error. Emotion, reason, and the human brain. New York: G.P. Putnam's Sons.

Enfield, Nick and Sidnell, Jack (2017). On the concept of action in the study of interaction. Discourse Studies, 19(5), 515-535.

Evans, Nicholas, Bergqvist, Henrik, and San Roque, Lila (2017). The grammar of engagement I: Framework and initial exemplification. Language and Cognition, online first, $1-31$.

Foolen, Ad (2016). Expressives. In Nick Riemer (ed.), The Routledge handbook of semantics. London and New York: Routledge, 473-490.

Grundy, Peter (1995). Doing pragmatics. London: Arnold.

Huang, Yan (2014). Pragmatics. Second edition. Oxford: Oxford University Press.

Huang, Yan (Ed.) (2017). The Oxford handbook of pragmatics. Oxford: Oxford University Press.

Kecskés, István (2014). Intercultural pragmatics. Oxford: Oxford University Press.

Larina, Tatiana (2015). Culture-specific communication styles as a framework for interpreting linguistic and cultural idiosyncracies. International Review of Pragmatics, 7 195-215.

Leech, Geoffrey N. (1983). Principles of pragmatics. London and New York: Longman.

Levinson, Stephen C. (1983). Pragmatics. Cambridge: Cambridge University Press.

Martin, James R. and White, Peter R.R. (2005). The language of evaluation. Appraisal in English. New York: Palgrave Macmillan.

Senft, Gunter (2014). Understanding pragmatics. London and New York: Routledge.

Thompson, Geoff and Alba-Juez, Laura (Eds.) (2014). Evalution in context. Amsterdam: Benjamins.

van Dijk, Teun A. (1978). Taal en handelen. Een interdiscplinaire inleiding in de pragmatiek. [Language and action. An interdisciplinary introduction to pragmatics]. Muiderberg: Coutinho. 
Verschueren, Jef (1999). Understanding pragmatics. London: Arnold.

Yus, Francisco (2011). Cyberpragmatics. Internet-mediated communication in context. Amsterdam: Benjamins.

\section{For citation:}

Foolen, Ad (2018). Review of Laura Alba-Juez and J. Lachlan Mackenzie, 2016. Pragmatics: Cognition, Context \& Culture. Madrid: McGraw Hill, 307pp. Russian Journal of Linguistics, 22 (1), 195-199. doi 10.22363/2312-9182-2018-22-1-195-199.

\section{Bionote:}

AD FOOLEN has been teaching courses in all subfields of Linguistics at Radboud University Nijmegen from 1975 till 2015. His earlier research focused on modal particles in Dutch and German, in recent years he expanded his research field to the relation between language and emotion. From 2005 till 2017, he was secretary/treasurer of ICLA, the International Cognitive Linguistics Association. He is a member of the Editorial Board of several journals, among them Linguistics, Cognitive Linguistics, Cognitive Linguistic Studies, and Journal of Pragmatics. For his publications, see: http://www.ru.nl/grammarandcognition/people/vm/people/ad_foolen/publications/

\section{Для цитирования:}

Foolen, Ad (2018). Review of Laura Alba-Juez and J. Lachlan Mackenzie, 2016. Pragmatics: Cognition, Context \& Culture. Madrid: McGraw Hill, 307pp. Russian Journal of Linguistics, 22 (1), 195-199. doi 10.22363/2312-9182-2018-22-1-195-199.

\section{Сведения об авторе:}

AD FOOLEN преподавал различные лингвистические дисциплины в Университете Неймегена (Нидерланды) с 1975 по 2015 год. Его ранние исследования были посвящены модальным частицам в голландском и немецком языках. В последние годы он расширил сферу своих исследований, посвятив их выражению эмоций в языке. С 2005 по 2017 год он был секретарем Международной ассоциации по когнитивной лингвистики (ICLA). В настоящее время является членом редакционных коллегии нескольких журналов, среди которых Linguistics, Cognitive Linguistics, Cognitive Linguistic Studies, Journal of Pragmatics. С его научными публикациями можно ознакомиться на сайте: http://www.ru.nl/grammarandcognition/people/vm/people/ad_foolen/publications/ 